\title{
Insulin-Like Growth Factors I and II and Their Binding Proteins in Rat Milk
}

\author{
SHARON M. DONOVAN, RAYMOND L. HINTZ, DARRELL M. WILSON, AND \\ RON G. ROSENFELD \\ Department of Pediatrics, Division of Endocrinology and Metabolism, Stanford University Medical Center, \\ Stanford, California 94305
}

\begin{abstract}
IGF-I and -II are peptide growth factors that may be important contributors to the growth-promoting properties associated with milk. IGF in extracellular fluids, including serum and milk, are carried by specific highaffinity binding proteins (IGFBP). In this study, the levels of IGF-I and -II in rat serum and milk were quantified by specific RIA, and the IGFBP were characterized using Western ligand blotting and autoradiography throughout lactation. The levels of IGF-I in both milk and maternal serum decreased during lactation. Serum IGF-I decreased from $743 \pm 187 \mu \mathrm{g} / \mathrm{L}$ on $d 1$ to $391 \pm 106$ (mean $\pm \mathrm{SD})$ on d 21 of lactation, and milk IGF-I levels fell from $30 \pm$ 10 to $13 \pm 8 \mu \mathrm{g} / \mathrm{L}$. Levels of IGF-II in serum and milk were much lower than IGF-I, and were unaffected by lactation. In maternal serum, several IGFBP were identified: IGFBP-3, which migrates as four glycosylated bands with apparent $M_{r}$ from 38 to $42 \mathrm{kD}$ and one to two nonglycosylated bands with apparent $M_{r}$ of 28 to $29 \mathrm{kD}$, and an IGFBP with an apparent $M_{r}$ of $24 \mathrm{kD}$. In milk, IGFBP-3, the 24-kD binding protein, and a third IGFBP with an apparent $M_{r}$ of $29 \mathrm{kD}$ were identified. Treatment of milk and serum with Endoglycosidase $F$ reduced the four glycosylated IGFBP-3 bands (38-42 kD) to two bands with apparent $M_{r}$ of 35 and $32 \mathrm{kD}$. In rat milk, but not adult rat serum, the IGFBP with an apparent $M_{r}$ of $29 \mathrm{kD}$ was immunoprecipitable by an antibody that recognizes IGFBP-2. These results demonstrate that in adult rat serum and milk both IGF-I and IGF-II are present, with IGF-I being predominant. IGFBP are present in rat milk; the presence of IGFBP-2 in rat milk, but not in maternal serum, indicates that IGFBP may be synthesized within the mammary gland. (Pediatr Res 29: 50-55, 1991)
\end{abstract}

\section{Abbreviations}

IGFBP, insulin-like growth factor binding proteins TBS, Tris-buffered saline au, absorbance unit

Milk contains growth factors that have been shown to be potent stimulators of DNA synthesis and proliferation in a variety of cells in culture (1-3). Among the growth factors present in human (4-6), bovine (7), and porcine (8) milks are the IGF. IGF-I and -II are growth hormone-dependent peptides that share structural and functional homology with insulin and may play

Received June 21, 1990; September 4, 1990

Correspondence: Dr. Sharon Donovan, Department of Pediatrics, Division of Endocrinology and Metabolism, Rm S-322, Stanford University Medical Center, Stanford, CA 94305

Supported in part by NIH Grant DK-28229 (R.G.R.). S.M.D. is a recipient of National Research Service Award HD-07226 from the NIH. an important role in early postnatal growth and development $(9$ 10). The IGF are present in serum and other extracellular fluids associated with a family of structurally related binding proteins (IGFBP) (11). In the human, three immunologically and genetically distinct binding proteins have been isolated, cloned, and sequenced and designated hIGFBP-3 (12), hIGFBP-2 (13), and hIGFBP-1 (14). Several other distinct binding proteins appear likely $(15,16)$.

In the rat, three IGFBP that are structurally homologous to the human IGFBP have recently been characterized. Baxter and Martin (17) demonstrated that the predominant IGFBP in adult rat serum is highly homologous to the glycosylated hIGFBP-3. This protein has been recently cloned, sequenced, and designated rIGFBP-3 (18). A second rat IGFBP, first isolated from the conditioned media of the rat hepatoma-derived cell line BRL$3 \mathrm{~A}$, has been cloned and identified as a nonglycosylated protein with an apparent $\mathbf{M}_{\mathrm{r}}$ of $29.5 \mathrm{kD}$ (rIGFBP-2) $(19,20)$. IGFBP-2 is the predominant IGFBP in neonatal rat serum, and disappears by the time of weaning $(21,22)$. A third rat IGFBP, rIGFBP-1, has recently been cloned from a rat deciduoma library using a cDNA for hIGFBP-1 (23). rIGFBP-1 has been shown to be secreted by the rat hepatoma cell line H-35 (24). In addition, both human and rat serum contains an IGFBP with an apparent $\mathrm{M}_{\mathrm{r}}$ of $24 \mathrm{kD}$ that has not yet been cloned and sequenced (21, 24).

Milk provides the sole source of nutrition for the neonatal rat for at least the first $2 \mathrm{wk}$ postpartum and may represent a significant source of exogenous growth-promoting factors for the neonate $(25,26)$. Receptors for the IGF have been identified in the intestines of suckling animals, indicating a possible function for milk-borne growth factors in intestinal development $(8,27)$. Due to the potential role of the IGF in the growth and development of the neonate, it is of interest to quantify the levels of these growth factors in milk. In addition, the IGFBP increase the stability of the IGF by slowing degradation (28), and modulate the access of IGF to membrane receptors. Their presence in milk may thus be of importance.

\section{MATERIALS AND METHODS}

Peptides. Pure biosynthetic human $\left[{ }^{59} \mathrm{Thr}\right] \mathrm{IGF}-\mathrm{I}$ was purchased from Amgen Biologicals (Thousand Oaks, CA). Recombinant human IGF-II was generously provided by Dr. Michelle Smith (Lilly, Indianapolis, IN). Iodination was performed by a modification of the chloramine-T technique.

Biologic samples. Timed pregnant Wistar rats $(n=45)$ were obtained on d 14 of gestation (Simonsen, Gilroy, CA). Dams were housed singly in animal facilities maintained at $25^{\circ} \mathrm{C}$ with 12-h light-dark cycles. Dams were allowed ad libitum access to food (Wayne Rodent Blox, Premier Laboratory Diets, Bartonville, IL) and water. After delivery, which was designated d 1 of lactation, litters were normalized to 10 pups per dam. Serum and milk samples were collected from dams on d 1-4, 7, 10, 14, 
18 , and 21 of lactation. Pups were removed from the dams $3 \mathrm{~h}$ before milking. Dams were injected intramuscularly with $0.1 \mathrm{~mL}$ synthetic oxytocin (200 IU/mL; Sigma Chemical Co., St. Louis, MO) 15 min before milking and were anesthetized during milking. Blood was collected by cardiac puncture under anesthetic. Blood samples were allowed to clot at $4^{\circ} \mathrm{C}$ for $30 \mathrm{~min}$ and were centrifuged at $10000 \times g$ at $4^{\circ} \mathrm{C}$ for $15 \mathrm{~min}$ to separate serum. Milk samples were centrifuged at $180000 \times g$ (Beckman LM-2 ultracentrifuge, SW-60ti rotor, Beckman Instruments, Inc., Palo Alto, CA) at $4^{\circ} \mathrm{C}$ for $45 \mathrm{~min}$ to separate the whey (infranatant) from the fat (supernatant) and casein (pellet) fractions before analysis. Whole milk and milk fractions from d 14 of lactation were assayed for IGF binding activity by ligand blot analysis. All samples were stored at $-70^{\circ} \mathrm{C}$ before analysis. All animal protocols were approved by the Administrative Panel on Laboratory Animal Care at Stanford University.

$I G F$ quantification. To dissociate the IGF from the binding proteins, serum and whey samples were chromatographed in $0.25 \mathrm{M}$ formic acid on a $0.9 \times 100-\mathrm{cm}$ column containing Sephadex G-50 (Pharmacia Fine Chemicals, Piscataway, NJ). The fractions eluting between 50 and $67 \mathrm{~mL}$, which contain $90 \%$ of the IGF activity for both whey and serum and no demonstrable IGFBP, were collected in siliconized glass tubes containing 1.0 $\mathrm{mL}$ of $1.0 \%$ BSA, frozen, and lyophilized (29). Samples were resolublized in RIA buffer $(0.04 \mathrm{M}$ sodium phosphate, $0.15 \mathrm{M}$ sodium chloride, $0.5 \%$ BSA, $0.1 \%$ sodium azide) to their original volume before assay. The assay was run using $25-, 50-$, and $100-$ $\mu \mathrm{L}$ samples, and parallel dose-response curves were seen for both serum and whey (data not shown). IGF-I content was measured by RIA using [ ${ }^{125}$ I]IGF-I as radioligand and a polyclonal antisomatomedin-C/IGF-I antibody. This antiserum (UBK487) was generated by Drs. L. E. Underwood and J. J. Van Wyk, University of North Carolina at Chapel Hill, and is distributed through the Hormone Distribution Program of the National Institute of Diabetes and Digestive and Kidney Diseases to the National Hormone and Pituitary Program. Inter- and intraassay coefficients of variation for the IGF-I assay were 8 and 5\%, respectively. IGF-II content was measured by RIA using recombinant ${ }^{125}$ I]IGF-II and a MAb against rat IGF-II that has less than $10 \%$ cross-reactivity with human IGF-I (Amano, Troy, VA). Interand intraassay coefficients of variation for the IGF-II assay were 10 and $6 \%$, respectively. Serum samples were run at a 1:100 dilution for IGF-I. Milk IGF-I and serum and milk IGF-II were determined using undiluted samples. The lower limits of sensitivity for both assays is approximately $1.0 \mu \mathrm{g} / \mathrm{L}$ in the original sample.

$S D S-P A G E$. SDS-PAGE was performed according to the method of Laemmli (30). Twenty $\mu \mathrm{L}$ of a 1:10 dilution of serum or a $1: 2$ dilution of milk were applied to a $4 \%$ stacking gel and electrophoresed through a $10 \%$ polyacrylamide gel. Comparable amounts of proteins were loaded for both serum and milk (approximately $0.8 \mathrm{~g}$ protein/lane). Prestained molecular weight standards (BRL, Bethesda, MD) were run in parallel lanes. Some IGFBP samples were enzymatically deglycosylated using Endoglycosidase F (Endo F; Calbiochem, La Jolla, CA) as previously described (31). Briefly, samples $(20 \mu \mathrm{L})$ were adjusted to $\mathrm{pH} 5.5$ and $240 \mathrm{mU}$ of Endo $\mathrm{F}$ were added; after incubation at $37^{\circ} \mathrm{C}$ for $3 \mathrm{~h}$, reactions were terminated by the addition of an equal volume of electrophoresis buffer. Samples were applied to a $10 \%$ SDSPAGE gel and electrophoresed overnight at $50 \mathrm{~V}$.

Electrotransfer and Western ligand blotting. Western ligand blotting was performed following the method of Hossenlopp et al. (32). Briefly, after electrophoresis polyacrylamide gels were washed in Towbin buffer ( $0.025 \mathrm{M}$ Tris-base, $0.192 \mathrm{M}$ glycine, $20 \%$ methanol) (33) for $15 \mathrm{~min}$ to remove SDS before electrotransfer. Proteins were electroblotted onto nitrocellulose $(0.45$ $\mu \mathrm{m}$, Schleicher and Schuell Inc., Keene, NH) using a Gelman Biotrans semidry electrophoresis transfer unit (Gelman Sciences, Ann Arbor, MI) at $180 \mathrm{~mA}$ for $90 \mathrm{~min}$, using Towbin buffer. Nitrocellulose membranes were washed with TBS $(0.15 \mathrm{M}$ so- dium chloride, $0.01 \mathrm{M}$ Tris- $\mathrm{HCl}$ ) containing $3 \%$ Nonidet $\mathrm{P}-40$ (NP-40, Sigma Chemical Co.). Membranes were blocked with TBS containing 1\% BSA (Sigma Chemical Co.) for $2 \mathrm{~h}$, followed by TBS containing $0.1 \%$ Tween for $10 \mathrm{~min}$. The membranes were then incubated overnight at $4^{\circ} \mathrm{C}$ with approximately $1.5 \times$ $10^{6} \mathrm{cpm}$ of [ ${ }^{125}$ I]IGF-I or [ ${ }^{125}$ I] IGF-II in $10 \mathrm{~mL}$ of TBS containing $1 \%$ BSA and $0.1 \%$ Tween. Membranes were washed with TBS, air-dried, and visualized by exposure to Kodak X-Omat AR film (Rochester, NY) for $4-14 \mathrm{~d}$ at $-70^{\circ} \mathrm{C}$. Autoradiograms were scanned using laser densitometry and total au. $\mathrm{mm}$ were calculated for each lane (UltraScan XL; LKB, Bromma, Sweden).

Immunoprecipitation. A polyclonal antibody to partially purified human IGFBP (hIGFBP-2 and hIGFBP-3) secreted by the human endometrial adenocarcinoma cell line HEC IA $(\alpha \mathrm{HEC}$ 1) was generated in New Zealand White rabbits and protein $A$ purified, as previously described (31). In the rat, this antibody has been shown to be specific for rIGFBP-2, inasmuch as it does not recognize rIGFBP-3 (21). To immunoprecipitate rIGFBP-2 in rat milk and serum, Staphylococcal aureas protein A (Pansorbin, Calbiochem) was washed in Tris buffer $(50 \mathrm{mM}$ Tris $\mathrm{HCl}$, $\mathrm{pH}$ 7.4) and resuspended in Tris buffer at the original volume. Fifty $\mu \mathrm{L}$ of the washed protein A were incubated with $5 \mu \mathrm{L}$ of $\alpha \mathrm{HEC} 1$ or $5 \mu \mathrm{L}$ of normal rabbit serum on a rotating shelf at $4^{\circ} \mathrm{C}$ overnight. Milk ( $40 \mu \mathrm{L}, 1: 2$ dilution) and serum $(40 \mu \mathrm{L}, 1: 10$ dilution) samples were then added to the antibody-Staph $\mathrm{A}$ complex and incubated at $4^{\circ} \mathrm{C}$ on a rotating shelf for $3 \mathrm{~h}$. Samples were centrifuged at $10000 \times g$ for $5 \mathrm{~min}$ and the pellet washed three times with Tris buffer. Samples were prepared for electrophoresis by the addition of sample buffer (Tris-SDS, glycerol), vortexed, boiled for $5 \mathrm{~min}$, revortexed vigorously, and centrifuged at $10000 \times g$ for $5 \mathrm{~min}$. The resulting supernatants were electrophoresed, electrotransferred, and ligand-blotted with $\left[{ }^{125} \mathrm{I}\right]$ IGF, as previously described.

Statistical analysis. Differences in milk and serum IGF peptide concentrations were analyzed using a nonpaired analysis of variance and differences were considered significant if $p<0.05$ by Fischer protected least significant difference test (Statview, Brainpower, Inc., Santa Monica, CA). Correlations between milk and serum IGF and IGFBP were determined by Pearson's method.

\section{RESULTS}

Serum and milk IGF-I and IGF-II concentrations. Serum IGFI and IGF-II concentrations throughout lactation are presented in Table 1. Rat serum IGF-I content decreased significantly $(p=$ 0.05 ) during lactation, from mean \pm SD levels of $743 \pm 187$ on the first postpartum $\mathrm{d}$ to $391.7 \pm 38.1 \mu \mathrm{g} / \mathrm{L}$ by $\mathrm{d} 21$ postpartum. This compares to a concentration of $577 \pm 77 \mu \mathrm{g} / \mathrm{L}$ for IGF-I in virgin females. The major drop in serum IGF-I concentration occurred between d 3 and 4 postpartum, with levels staying relatively constant thereafter. Serum IGF-II levels in the adult

Table 1. IGF-I and IGF-II in rat serum and milk throughout lactation $(\mu g / L)^{*}$

\begin{tabular}{cccccc} 
& \multicolumn{2}{c}{ IGF-I } & & \multicolumn{2}{c}{ IGF-II } \\
\cline { 2 - 3 } \cline { 5 - 6 } Day & Serum & Milk & & Serum & Milk \\
\hline 1 & $743 \pm 187$ & $30 \pm 10.0$ & & $9.3 \pm 6.7$ & $1.3 \pm 0.5$ \\
2 & $833 \pm 201$ & $29 \pm 5.3$ & & $7.0 \pm 2.0$ & $1.0 \pm 0.3$ \\
3 & $907 \pm 238$ & $26 \pm 5.3$ & & $6.3 \pm 1.2$ & $<1$ \\
4 & $558 \pm 62$ & $26 \pm 3.6$ & & $9.0 \pm 1.0$ & $<1$ \\
7 & $461 \pm 68$ & $18 \pm 4.3$ & & $4.0 \pm 1.0$ & $<1$ \\
11 & $440 \pm 56$ & $18 \pm 3.5$ & & $6.3 \pm 1.5$ & $<1$ \\
14 & $501 \pm 71$ & $17 \pm 7.8$ & & $7.0 \pm 0.1$ & $<1$ \\
18 & $449 \pm 105$ & $15 \pm 6.1$ & $5.3 \pm 0.6$ & $<1$ \\
21 & $392 \pm 38$ & $13 \pm 8.0$ & & $4.5 \pm 0.6$ & $<1$ \\
Control $\dagger$ & $577.0 \pm 77.0$ & & & & \\
\hline
\end{tabular}

* Values represent mean \pm SD of five animals/d

+ Virgin females of similar age and weight. 


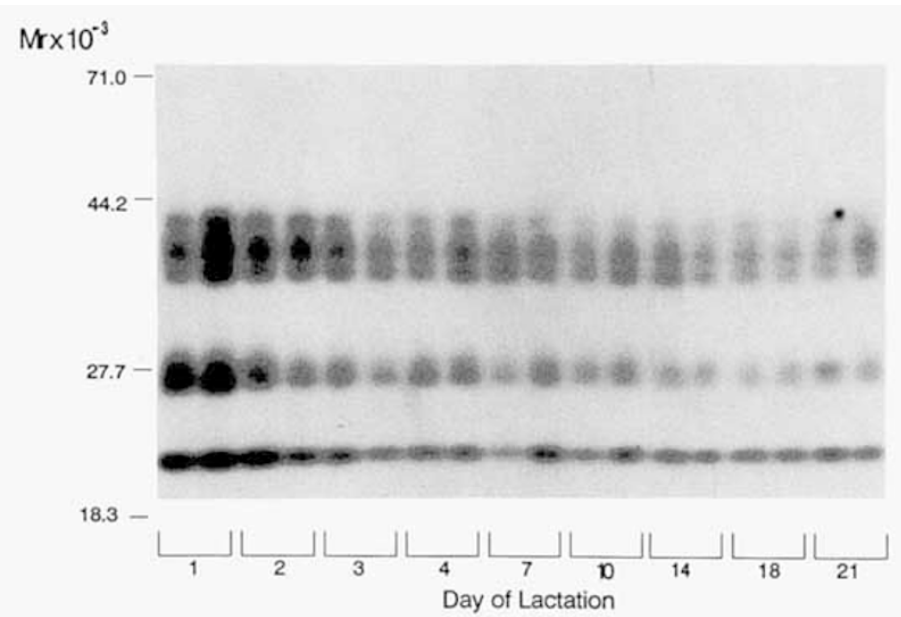

Fig. 1. Rat serum IGFBP throughout lactation. Autoradiograph of a Western ligand blot of rat serum during lactation. Each lane represents samples from a different dam. Samples $(20 \mu \mathrm{L} ; 1: 10$ dilution) were separated by SDS-PAGE on a $10 \%$ gel, Western ligand blotted using [ ${ }^{125}$ I]IGF-I, and exposed to film for $4 \mathrm{~d}$. Bands with apparent $\mathrm{M}_{\mathrm{r}}$ of 3842,28 , and $24 \mathrm{kD}$ were visualized.

Table 2. IGFBP in rat serum and milk throughout lactation $(a u \cdot m m)^{*}$

\begin{tabular}{ccc}
\hline Day & Serum $\dagger$ & Milk $\ddagger$ \\
\hline 1 & $16.9 \pm 5.2$ & $5.4 \pm 0.7$ \\
2 & $11.2 \pm 1.1$ & $6.2 \pm 1.2$ \\
3 & $7.4 \pm 2.1$ & $5.6 \pm 3.9$ \\
4 & $7.3 \pm 0.7$ & $6.8 \pm 1.7$ \\
7 & $5.3 \pm 1.0$ & $3.7 \pm 3.1$ \\
10 & $5.6 \pm 1.9$ & $6.4 \pm 0.1$ \\
14 & $4.6 \pm 1.7$ & $5.8 \pm 0.1$ \\
18 & $3.1 \pm 0.2$ & $3.5 \pm 0.1$ \\
21 & $4.4 \pm 0.1$ & $3.2 \pm 0.1$ \\
\hline
\end{tabular}

* Values represent mean \pm SD of two animals/d.

† Serum data from densitometric analysis of Figure 1.

$\ddagger$ Milk data from densitometric analysis of Figure 3.

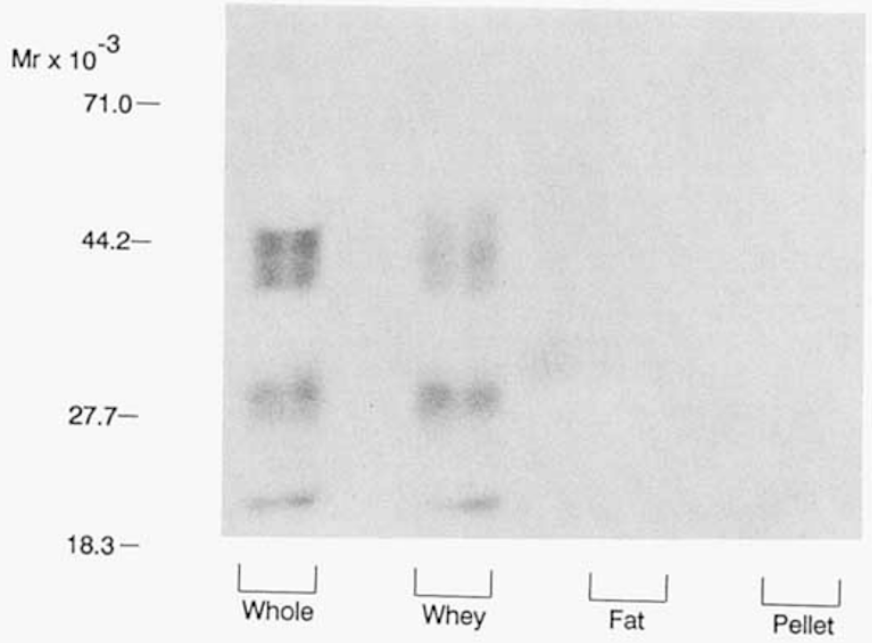

Fig. 2. Comparison of IGFBP in whole rat milk and milk fractions Autoradiograph of a Western ligand blot of rat milk and milk fractions from d 14 of lactation. Milk fractions were separated by ultracentrifugation at $180000 \times g$ at $4^{\circ} \mathrm{C}$ into fat, whey, and pellet (casein) fractions. Samples $(20 \mu \mathrm{L}$; whole milk $1: 2$ dilution and whey $1: 2$ dilution, fat undiluted and pellet undiluted) were separated by SDS-PAGE on a $10 \%$ gel, Western ligand blotted using [ ${ }^{125}$ I]IGF-I, and exposed to film for 14 d. Bands with apparent $M_{r}$ of $38-42,29,28$, and $24 \mathrm{kD}$ were visualized.

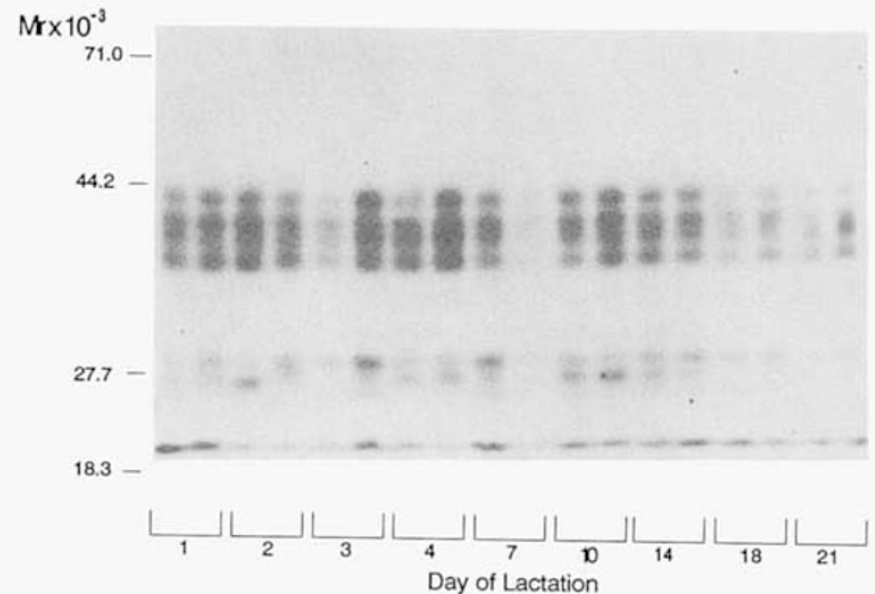

Fig. 3. Rat milk IGFBP throughout lactation. Autoradiograph of a Western ligand blot of rat milk whey during lactation. Each lane represents samples from a different dam. Whey samples ( $20 \mu \mathrm{L} ; 1: 2$ dilution) were separated by SDS-PAGE on a $10 \%$ gel, Western ligand blotted using [ ${ }^{125}$ I]IGF-I, and exposed to film for $7 \mathrm{~d}$. Bands with apparent $\mathrm{M}_{\text {r }}$ of $38-42,29,28,27$, and $24 \mathrm{kD}$ were visualized.

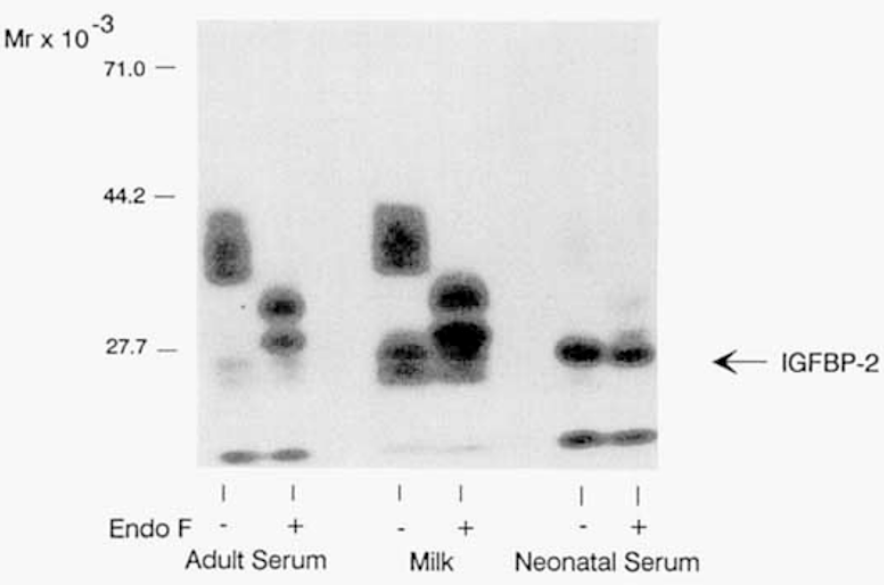

Fig. 4. Deglycosylation of rat milk and adult and neonatal rat serum IGFBP by Endoglycosidase F. Autoradiograph of a Western ligand blot of samples deglycosylated with Endoglycosidase F. Whey samples (20 $\mu \mathrm{L} ; 1: 2$ dilution) and serum samples ( $20 \mu \mathrm{L} ; 1: 10$ dilution) were deglycosylated by Endoglycosidase $F$ for $3 \mathrm{~h}$ at $37^{\circ} \mathrm{C}$. All samples were from postpartum $d 4$. Native and deglycosylated samples were separated by SDS-PAGE on a $10 \%$ gel, Western ligand blotted using [ $\left[{ }^{125}\right.$ I]IGF-I, and exposed to film for $7 \mathrm{~d}$. Bands with apparent $\mathrm{M}_{\mathrm{r}}$ of $38-42,29,28$, and $24 \mathrm{kD}$ were visualized. The arrow indicates the location of rIGFBP- 2 .

rat are extremely low (34), with levels in this study ranging between 4.0 and $9.0 \mu \mathrm{g} / \mathrm{L}$, or $1-2 \%$ of the serum IGF-I levels. Serum IGF-II concentration in the serum of virgin rats was 10 $\pm 3.0 \mu \mathrm{g} / \mathrm{L}$. Serum IGF-II concentrations were unaffected by lactation. The levels of IGF-I and -II in rat milk are also shown in Table 1. Milk IGF-I content decreased during lactation from $30 \pm 10 \mu \mathrm{g} / \mathrm{L}$ on $\mathrm{d} 1$ of lactation to $13 \pm 8.0 \mu \mathrm{g} / \mathrm{L}$ on $\mathrm{d} 21$ of lactation. IGF-II concentration in rat colostrum (d $1-2$ postpartum) was $1.0-1.3 \mu \mathrm{g} / \mathrm{L}$; after $\mathrm{d} 2$ the levels fell below $1.0 \mu \mathrm{g} / \mathrm{L}$, which is below the lowest level of detection for our assay.

Western ligand blot of rat serum IGFBP. A Western ligand blot of IGFBP in rat serum throughout lactation, visualized with $\left[{ }^{125}\right.$ I]IGF-I, is shown in Figure 1. Adult rat serum contains six bands with apparent $M_{r}$ values of $42,41,40,38,28$, and $24 \mathrm{kD}$. The bands migrating at $38-42 \mathrm{kD}$ and the $28-\mathrm{kD}$ band, a proteolytic fragment of the $38-$ to $42-\mathrm{kD}$ bands, have previously been identified to be rIGFBP-3 (35). In some serum samples, a doublet can be observed in the $28-$ to $29-\mathrm{kD}$ region. These bands most likely represent rIGFBP-2 (29 kD) and the proteolytic 
inhibit the actions of the IGF on their target tissues $(39,40)$, or, conversely, potentiate IGF action $(41,42)$. In addition to being present in the circulation, mRNA for both IGF-I and IGF-II have been identified in multiple organ systems throughout the body, suggesting that the growth factors may be synthesized and act locally via paracrine or autocrine mechanisms (43) and be regulated by locally produced IGFBP (39-41).

Several lines of research have indicated that the IGF are important mediators of mammary growth and development. IGF-I has previously been described in the milk of a variety of species (4-8) and has been shown to be a potent stimulator of mammary cell growth and DNA synthesis in cultured bovine (44) and ovine (45) mammary tissue. In addition, increased milk production observed when growth hormone is administered to the cow (46) or the goat (47) may be mediated via IGF-I. Lastly, both type I and type II IGF receptors have been characterized on bovine mammary plasma (48) and microsomal (47) membranes and rat mammary tissue (49). In both the cow and the rat, the onset of lactation is associated with a dramatic increase in IGF binding to mammary tissue, which is mainly due to an increase in the number of type II rather than type I receptors $(49,50)$.

In this study, we have characterized the presence of IGF-I and -II in rat serum and milk throughout lactation. IGF-I represents the predominant IGF in adult rat serum and milk. The levels of IGF-I in rat milk are 30 to 50 times higher than the IGF-II levels, but are present at only 3-5\% of the levels found in serum from the lactating rat. IGF-I in serum and milk decreased after the first 3 to $4 \mathrm{~d}$ of lactation, and then remained stable throughout the remainder of lactation. Concentrations of IGF-I and -II in rat milk are compared with milks of other species in Table 3. IGF-I levels of $25-30 \mu \mathrm{g} / \mathrm{L}$ in rat colostrum are in the range of what has been reported in human milk $(7-27 \mu \mathrm{g} / \mathrm{L})$, but are far below the levels reported in bovine $(100-600 \mu \mathrm{g} / \mathrm{L})$ and porcine $(67-357 \mu \mathrm{g} / \mathrm{L})$ colostrum. Levels of IGF-I in mature rat milk ranges from 13-18 $\mu \mathrm{g} / \mathrm{L}$, which is comparable to the levels reported in the milks of other species (Table 3). The levels of IGF-II in rat milk also decrease after the first few days of lactation, although the levels are extremely low even in early lactation. The concentrations of IGF-II in human and porcine milk are currently unreported.

The source of the IGF in rat milk is not known. Messenger RNA for both IGF-I and -II were very low, or undetectable, in rat mammary glands isolated from dams d 11 postpartum (43), suggesting that maternal serum is the most likely source of IGF. Previous studies with epidermal growth factor in mice (51) and goats (52) demonstrated the transfer of epidermal growth factor from maternal circulation, most likely via epidermal growth factor receptors located in the mammary glands. The presence of IGF receptors in mammary tissue may sequester IGF from the maternal serum in an analogous manner. In the rat, suckling stimulus is necessary for final differentiation of the mammary glands. Therefore, the elevated levels of both IGF-I and -II observed in early lactation may represent leakage from the maternal circulation via paracellular or "leaky" junctions. Alternatively, a major role for IGF in the mammary gland may be to stimulate either the growth or differentiated function of the mammary epithelial cells. Therefore, the levels of IGF-I and -II in milk may simply represent intracellular mammary IGF that is released during milk secretion. It is interesting to note that although serum and milk IGF-I were significantly correlated with one another, the correlation was rather weak $\left(r^{2}=0.25\right)$, suggesting that serum may not be the sole source of the milk IGFI.

IGF binding proteins have been demonstrated in human (46) and cow (53) milk, and have been shown to be secreted by bovine mammary glands in culture (54). In our study, the presence of rIGFBP-2 in milk, but not in the serum of the lactating rat, and the lower levels of the $24-\mathrm{kD}$ binding protein in milk than in maternal serum suggest that some IGFBP are synthesized in rat mammary epithelium rather than transported from the maternal circulation. The observation that the levels of IGFBP-2 in maternal serum are absent or extremely low $(21,22)$ and the absence of detectable message for rIGFBP-2 in adult rat liver (55) further support the hypothesis of de novo synthesis within the mammary gland. In addition, there is a relatively weak correlation between the levels of IGFBP-3 in maternal serum and milk $\left(r^{2}=0.34\right)$. Further studies of rat mammary gland using probes for rIGFBP mRNA may elucidate the source of IGFBP in milk.

Growth factors contained in milk, particularly epidermal growth factor, have been postulated to have a role in the developing gastrointestinal tract (25). The gastrointestinal tract undergoes rapid growth and proliferation during the neonatal period. The presence of colostrum or early milk has been shown to stimulate intestinal growth in the suckling rat (26). Although a direct role for the milk-borne IGF remains to be demonstrated, the presence of both type I and type II IGF receptors in the intestinal epithelium of rats suggests that exogenous IGF may be able to interact with the intestine and elicit mitogenic responses (27). A role of IGF in intestinal growth is supported by increased binding of IGF to proliferative intestinal cells, located in the crypts, than to the differentiated enterocytes located on the tips of the villi (27). In addition, a recent study investigating the absorption of ${ }^{125}$ I]IGF by the suckling rat demonstrated that approximately $78 \%$ of administered IGF-I was retained by the animals, predominantly in the stomach and intestinal lining (56). Because it appears that in the suckling animals IGF may partially survive digestion, further studies investigating the in vivo effects of IGF-I and -II on the developing rat intestine are warranted.

In summary, the presence of both IGF-I and IGF-II has been demonstrated in rat milk and serum during lactation. IGF-I is predominant in both adult rat serum and milk and decreases significantly after the first 3 to $4 \mathrm{~d}$ postpartum. The IGFBP in rat milk and serum have been characterized by Western ligand blotting. Adult rat serum contains predominantly rIGFBP-3 and a low molecular weight $24-\mathrm{kD}$ binding protein. In addition, very small amounts of rIGFBP-2 or rIGFBP-1 may be present. Rat milk contains rIGFBP-2, in addition to rIGFBP-3 and the 24$\mathrm{kD}$ binding protein, and may also contain small amounts of rIGFBP-1. Previous studies have demonstrated that although levels of rIGFBP-2 are high in the neonatal rat, rIGFBP-2 is virtually absent in the serum of the adult rat $(21,22)$; in this study we have confirmed by immunoprecipitation that no rIGFBP-2 was detectable in adult rat serum. Therefore, it appears that the rIGFBP-2 in milk arises from synthesis within the mammary gland. Further studies are necessary to elucidate the source of both the IGF and the IGFBP in rat milk and to determine the role of milk IGF in neonatal growth and development.

Acknowledgments. The authors thank Bonita Baker for chromatographic separation of samples and William Greenman and Amanda Leness for assistance in sample collection and analysis.

\section{REFERENCES}

1. Klagsburn M 1978 Human milk stimulates DNA synthesis and cellular proliferation in cultured fibroblasts. Proc Natl Acad Sci USA 75:5057-5061

2. Klagsburn M 1980 Bovine colostrum supports the serum-free proliferation of epithelial cells but not fibroblasts in long-term culture. J Cell Biol 84:808814

3. Read LC, Upton FM, Francis GL, Wallace JC, Dahlenburg GW, Ballard FJ 1984 Changes in the growth-promoting activity of human milk during lactation. Pediatr Res 18:133-139

4. Baxter RC, Zaltsman Z, Turte JR 1984 Immunoreactive somatomedin-C/ insulin-like growth factor I and its binding protein in human milk. J Clin Endocrinol Metab 58:955-959

5. Corps AN, Brown KD, Rees LH, Carr J, Prosser CG 1988 The insulin-like growth factor I content in human milk increases between early and full lactation. J Clin Endocrinol Metab 67:25-29

6. Suikkari A-M 1989 Insulin-like growth factor (IGF-I) and its low molecular weight binding protein in human milk. Eur J Obstet Gynecol Reprod Biol 30:19-25 


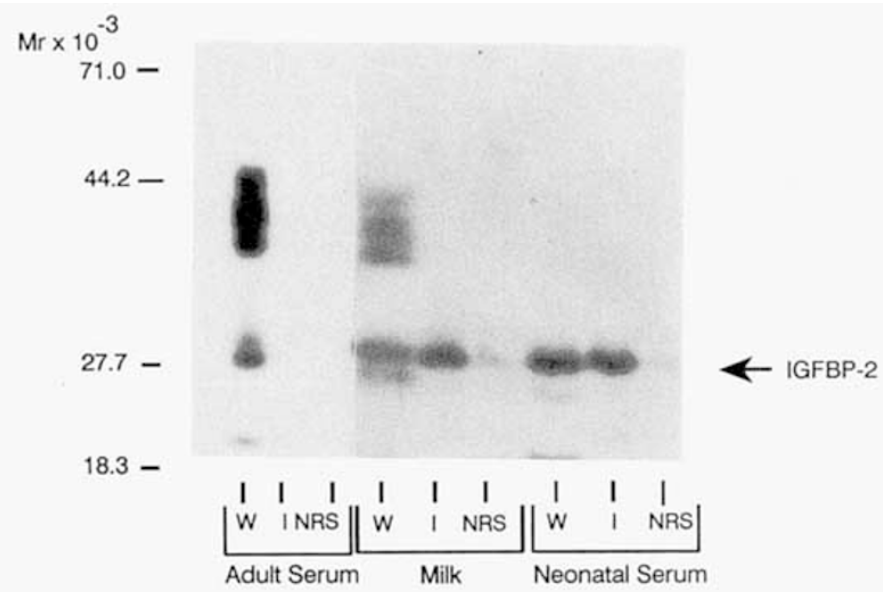

Fig. 5. Immunoprecipitation of rat milk and adult and neonatal serum IGFBP with $\alpha \mathrm{Hec} 1$ antibody. Autoradiograph of a Western ligand blot of adult rat serum (lanes 1-3), rat milk (lanes 4-6), and neonatal rat serum (lanes 7-9). All samples were from postpartum d 14. Each sample is represented in three lanes with the first lane being a ligand blot (W) (lanes 1,4 , and 7$)$, the second lane an immunoprecipitation with $\alpha \mathrm{Hec} 1$ (I) (lanes 2, 5, and 8), and the third lane an immunoprecipitation with nonimmune rabbit serum (NRS) (lanes 3,6 , and 9). Milk samples (40 $\mu \mathrm{L} ; 1: 2$ dilution) and serum sample (40 $\mu \mathrm{L} ; 1: 10$ dilution) were immunoprecipitated, then separated by SDS-PAGE on a $10 \%$ gel, Western ligand blotted using [ $\left.{ }^{125} \mathrm{I}\right] \mathrm{IGF}-\mathrm{I}$, and exposed to film for $10 \mathrm{~d}$. Bands with apparent $M_{r}$ of $38-42,29,28$, and $24 \mathrm{kD}$ were visualized. The arrow indicates the location of IGFBP-2.

Table 3. Comparison between milk IGF-I and IGF-II levels in milks of different species $(\mu g / L)$

\begin{tabular}{lccccc}
\hline & \multicolumn{2}{c}{ IGF-I } & & \multicolumn{2}{c}{ IGF-II } \\
\cline { 2 - 3 } \cline { 5 - 6 } Species & Colostrum & Mature & & Colostrum & Mature \\
\hline Human (4)* & $7-27$ & $6-9$ & & NA & NA \\
Pig (8) & $65-357$ & $4-14$ & & NA & NA \\
Cow (44) & $100-600$ & $22-26$ & & 600 & $107-127$ \\
Rat & $28-30$ & $13-18$ & & $1-2$ & $<1$ \\
\hline
\end{tabular}

* Numbers in parentheses denote the reference from which data was compiled. Rat data is from the current study.

$\dagger \mathrm{NA}=$ values not available.

fragment of rIGFBP-3 $(28 \mathrm{kD})(21,24)$. In addition, a $24-\mathrm{kD}$ IGFBP was identified in serum throughout lactation. Results of densitometric analysis of Figure 1 are shown in Table 2. Results for each day represent the mean $\pm \mathrm{SD}$ of the au.mm of the serum IGFBP for the two dams. Data is presented to show relative changes in IGFBP content throughout lactation. The level of IGFBP in maternal serum was higher during the first 4 $\mathrm{d}$ postpartum than in later lactation. The decrease in IGFBP activity during lactation mirrored that of the serum IGF-I content (Table 1).

Western ligand blot of rat milk IGFBP. A Western ligand blot of IGFBP in whole milk and the whey, fat, and casein fractions of rat milk, visualized with [ $\left.{ }^{125} \mathrm{I}\right] \mathrm{IGF}-\mathrm{I}$, is shown in Figure 2. IGFBP were identified only in whole milk and the whey fraction, validating the use of the whey fraction for further analysis. The presence of large amounts of casein protein in whole rat milk causes a compression of the IGFBP- 3 bands due to their similar molecular weights. The removal of casein by centrifugation was verified by staining the SDS-PAGE gel with Coomassie blue and comparing whole milk versus whey (data not shown). By removing the casein proteins by centrifugation, the compression of the IGFBP bands can be relieved, allowing better resolution of the autoradiographic bands. IGFBP in rat milk whey throughout lactation are shown in Figure 3. When electroblotted milk proteins were exposed to [ ${ }^{125} \mathrm{I}$ ]IGF-I, seven bands, with apparent $M_{r}$ values of $42,41,40,38,29,28$, and $24 \mathrm{kD}$, were identified. In some milk samples, an 8th band with an apparent $\mathrm{M}_{\mathrm{r}}$ of approximately $27 \mathrm{kD}$ was visualized. The triplet of bands migrating in the $29-$ to $27-\mathrm{kD}$ region have previously been identified as rIGFBP-2 (29 kD), rIGFBP-3 $(28 \mathrm{kD})$, and the proteolytic fragment of rIGFBP-1 $(27 \mathrm{kD})(24)$. In milk, the $24-\mathrm{kD}$ binding protein was less apparent than that observed in maternal serum and was absent in some samples. Results of densitometric analysis of Figure 3 are shown in Table 2. Results for each day represent the mean \pm SD of the au.mm for milk IGFBP from the two dams. Unlike the maternal serum, levels of IGFBP in milk did not show a significant decrease during lactation.

Effect of deglycosylation. The effect of deglycosylation of rat milk, adult rat serum, and neonatal rat serum is shown in Figure 4. In milk and adult rat serum, treatment with Endoglycosidase $F$ (Endo $F$ ) reduces the four higher molecular weight bands of rIGFBP-3 (42-38 kD) to two bands, with approximate $\mathrm{M}_{\mathrm{r}}$ of 35 and $32 \mathrm{kD}$. The apparent $M_{r}$ of the $24-\mathrm{kD}$ protein and of the 29-kD protein, which occur in neonatal serum and rat milk, were unaffected by Endo F digestion, confirming the lack of Nlinked glucosamine groups associated with these proteins. These results suggest that the predominant $29-\mathrm{kD}$ protein in milk is rIGFBP-2, which is nonglycosylated. In adult serum, the predominant band in the $28-$ to $29-\mathrm{kD}$ region is most likely the proteolytic fragment of rIGFBP-3 $(21,22,24)$, rather than rIGFBP-2. Previous investigators have demonstrated that this rIGFBP-3 band can be reduced to a band with an apparent $M_{r}$ of $24 \mathrm{kD}$ by deglycosylation with $\mathrm{N}$-glycanase (36).

Immunoprecipitation of IGFBP. Immunoprecipitation studies were performed to test for immunologic similarities between the IGFBP contained in adult and neonatal rat serum and rat milk. Samples were preincubated with either an antibody to rIGFBP$2(\alpha \mathrm{HEC} 1)$ or nonimmune rabbit serum. Immunoprecipitates were electrophoresed, electroblotted onto nitrocellulose, and exposed to [ ${ }^{125} \mathrm{I}$ ]IGF-II as described above. In Figure 5, each sample is represented in three separate lanes, with the first lane being a Western ligand blot, the second lane an immunoprecipitation with $\alpha$ HEC 1, and the third lane an immunoprecipitation with nonimmune rabbit serum. A band of approximately $29 \mathrm{kD}$ (rIGFBP-2) was visualized in both the Western ligand blots and the immunoprecipitations of neonatal rat serum and rat milk. It is of note that a band of the same approximate size is not immunoprecipitated from adult rat serum, confirming the paucity of rIGFBP-2 in adult rat serum $(21,22,24)$. The bands associated with rIGFBP-3 can be observed in the Western ligand blots of both adult rat serum and rat milk, but were not immunoreactive with $\alpha$ HEC 1 . In addition, the 24-kD binding protein, which is present in all samples, was not immunoprecipitated by the antibody. No bands were observed in samples incubated with nonimmune rabbit serum.

Regression analyses of rat milk and serum $I G F(\mu g / L)$ and $I G F B P(\mathrm{au} \cdot \mathrm{mm})$ content. The following comparisons were made by regression analysis: serum IGF-I versus milk IGF-I, serum IGFBP-3 versus milk IGFBP-3, serum IGF-I versus serum IGFBP-3, and milk IGF-I versus milk IGFBP-3. IGF-I concentrations in serum and milk were correlated $\left(r^{2}=0.25 ; p=0.03\right)$ as were serum and milk IGFBP-3 $\left(r^{2}=0.34 ; p=0.01\right)$. Serum IGF-I and IGFBP-3 were strongly correlated with an $r^{2}=0.76$ $(p=0.001)$, whereas milk IGF-I and IGFBP-3 were not significantly related $\left(r^{2}=0.13, \mathrm{NS}\right)$.

\section{DISCUSSION}

IGF-I and IGF-II are peptide growth factors that exhibit mitogenic effects and can stimulate functional differentiation (37, 38). IGF in serum and extracellular fluids are found to be associated with a family of binding proteins. Although the function of the IGFBP remains unknown, several potential actions have been proposed. IGFBP have been shown to prolong the $t_{1 / 2}$ of circulating IGF from several minutes to several hours (29), 
7. Francis GL, Read LC, Ballard J, Bagley CJ, Upton FM, Gravestock PM, Wallace JC 1986 Purification and partial sequence analysis of insulin-like growth factor-1 from bovine colostrum. Biochem J 233:207-213

8. Simmen FA, Simmen RCM, Reihnart G 1988 Maternal and neonatal somatomedin-C/insulin-like growth factor-1 (IGF-I) and IGF binding proteins during early lactation in the pig. Dev Biol 130:16-20

9. Van Wyk JJ 1984 The somatomedins: biological actions and physiologic control mechanisms. In: $\mathrm{Li} \mathrm{CH}$ (ed) Hormonal Proteins and Peptides, Vol 12, Academic Press, New York, pp 81-125

10. Glasscock GF, Gelber S, McGee-Tekula R, Lamson G, Rosenfeld RG 1990 Pituitary control of growth in the neonatal rat. Effects of neonatal hypophysectomy $(\mathrm{Hx})$ on somatic and organ growth, serum IGF-I and -II levels and expression of IGF binding proteins. Endocrinology 127:1792-1803

11. Adashi EY 1990 Coming of age of insulin-like growth factor binding proteins: major players in a complex equation. Am J Reprod Immunol 20:97-99

12. Wood WI, Cachianes G, Henzel WJ, Winslow GA, Spencer SA, Hellmiss R Martin JL, Baxter RC 1989 Cloning and expression of the growth hormonedependent insulin-like growth factor binding protein. Mol Endocrinol 2:1176-1185

13. Binkert C, Landwehr J, Mary J-L, Schwander J, Heinrich G 1989 Cloning, sequence analysis and expression of a cDNA encoding a novel insulin-like growth factor binding protein (IGFBP-2). EMBO J 8:2497-2502

14. Lee Y-L, Hintz RL, James PM, Lee PDK, Shively JE, Powell DR 1988 Insulin like growth factor (IGF) binding protein complementary deoxyribonucleic acid from human HEP G2 hepatoma cells: predicted protein sequence suggests an IGF binding domain different from those of IGF-I and IGF-II receptors. Mol Endocrinol 2:404-411

15. Mohan S, Bautista CM, Wergedal J, Baylink DJ 1989 Isolation of an inhibitory insulin-like growth factor (IGF) binding protein from bone cell-conditioned medium: a potential local regulator of IGF action. Proc Natl Acad Sci USA 86:8338-8342

16. Roghani M, Hossenlopp P, Lepage P, Balland A, Binoux M 1989 Isolation from human cerebrospinal fluid of a new insulin-like growth factor-binding protein with a selective affinity for IGF-II. FEBS Lett 255:253-258

17. Baxter RC, Martin JL 1987 Binding proteins for insulin-like growth factors in adult rat serum. Comparison with other human and rat binding proteins. Biochem Biophys Res Comm 147:408-415

18. Shimasaki S, Koba A, Mercado M, Shimonaka M, Ling N 1989 Complemen tary DNA of the high molecular weight rat insulin-like growth factor binding protein (IGF-BP3) and tissue distribution of its mRNA. Biochem Biophys Res Commun 165:907-912

19. Brown AL, Chiariotti L, Orlowski CC, Mehlman R, Burgess WH, Ackerman EJ, Bruni CB, Rechler MM 1989 Nucleotide sequence and expression of a cDNA clone encoding a fetal rat binding protein for insulin-like growth factors. J Biol Chem 264:5148-5154

20. Margot JB, Binkert C, Mary J-L, Landwehr J, Heinrich G, Schwander J 1989 A low molecular weight insulin-like growh factor binding protein from rat: cDNA cloning and tissue distribution of its messenger RNA. Mol Endocrino 3:1053-1060

21. Donovan SM, Oh Y, Pham H, Rosenfeld RG 1989 Ontogeny of the insulinlike growth factor binding proteins in the rat. Endocrinology 125:2621-2627

22. Romanus JA, Terrell JE, Yang YW-H, Nissley SP, Rechler MM 1986 Insulinlike growth factor carrier proteins in neonatal and adult rat serum are immunologically different: demonstration using a new radioimmunoassay for the carrier protein from BRL-3A rat liver cells. Endocrinology 118:17431758

23. Murphy LJ, Seneviratne C, Ballejo G, Croze F, Kennedy TG 1990 Identification and characterization of a rat decidual insulin-like growth factor binding protein complementary DNA. Mol Endocrinol 4:329-336

24. Yang YW-A, Brown AL, Orlowski CC, Graham DE, Tseng LY-H, Romanus JA, Rechler MM 1990 Identification of rat cell lines that preferentially express insulin-like growth factor binding proteins rlGFBP-1,2,3. Mol Endocrinol 4:29-38

25. Berseth CL, Lichtenberger LM, Moriss FH 1983 Comparison of the gastrointestinal growth-promoting effects of rat colostrum and mature milk in newborn rats in vivo. Am J Clin Nutr 37:52-60.

26. Corps AN, Brown KD 1987 Stimulation of intestinal cell proliferation in culture by growth factors in human and ruminant mammary secretions. J Endocrinol ! ! 3:285-290

27. Laburthe M, Rouyer-Fessarrd C, Gammeltoff S 1988 Receptors for insulinlike growth factors I and II in rat gastrointestinal epithelium. Am J Physiol 254:G457-G462

28. Cohen KL, Nissley SP 1976 The serum half-life of somatomedin activity: evidence for growth hormone dependence. Acta Endocrinol (Copenh) 83: 243-258

29. Horner JM, Hintz RL 1982 Comparison of 125-I-SM-A and 125-I-SM-C radioreceptor assays for somatomedin peptide content in whole and acid chromatographed plasma. J Clin Endocrinol Metab 47:1287-1295

30. Laemmli $\vee 1970$ Cleavage of structural proteins during the assembly of the head of bacteriophage T4. Nature 227:680-685

31. Lamson G, Oh Y, Pham H, Guidice LC, Rosenfeld RG 1989 Expression of two insulin-like growth factor binding proteins in a human endometrial cancer cell line: structural, immunological, and genetic characterization. J Clin Endocrinol Metab 69:852-859

32. Hossenlopp P, Seurin D, Segovia-Quinson B, Hardouin S, Binoux M 1986 Analysis of serum insulin-like growh factor binding proteins using western blotting: use of the method for titration of the binding proteins and competitive binding studies. Anal Biochem 154:138-143

33. Towbin H, Staehelin T, Gordon J 1979 Electrophoretic transfer of protein from polyacrylamide gels to nitrocellulose sheets: procedure and some ap plications. Proc Natl Acad Sci USA 76:4350-4354

34. Daughaday WH, Rotwein P 1989 Insulin-like growth factors $I$ and II. Peptide, messenger ribonucleic acid and gene structures, serum and tissue concentrations. Endocrine Rev 10:68-91

35. Zapf J, Born W, Chang J-Y, James P, Froesch R, Fischer JA 1988 Isolation and $\mathrm{NH}_{2}$-terminal amino acid sequences of rat serum carrier proteins for insulin-like growth factors. Biochem Biophys Res Commun 156:1187-1194

36. Yang YW-H, Wang J-F, Orlowski CC, Nissley SP, Rechler MM 1989 Structure, specificity and regulation of the insulin-like growth factor-binding proteins in adult rat serum. Endocrinology 125:1540-1555

37. Froesch ER, Schmid C, Schwander J, Zapf J 1985 Actions of insulin-like growth factors. Ann Rev Physiol 47:443-467

38. Clemmons DR, Van Wyk JJ 1985 Evidence for a functional role of endogenously produced somatomedin-like peptides in the regulation of DNA synthesis in cultured human fibroblasts and porcine smooth muscle cells. J Clin Invest 75:1914-1918

39. Zapf J, Schoenle E, Jagars G, Sand I, Grunwald J, Froesch ER 1979 Inhibition of the action of nonsuppressable insulin-like activity on isolated rat fat cells by binding to its carrier protein. J Clin Invest 63:1077-1084

40. Knauer DJ, Smith GL 1980 Inhibition of biological activity of multiplicationstimulating activity by binding to its carrier protein. Proc Natl Acad Sci USA 77:7252-7256

41. DeVroede MA, Tseng LY-H, Katsoyannis PG, Nissley SP, Rechler MM 1986 Modulation of insulinlike growth factor I binding to human fibroblast monolayer cultures by insulinlike growth factor carrier proteins released to the incubation media. J Clin Invest 77:602-613

42. Elgin RG, Busby Jr WH, Clemmons DR 1987 An insulin-like growth factor binding protein enhances the biologic response to IGF-I. Proc Natl Acad Sci USA 84:3254-3258

43. Murphy L, Bell GI, Friesen HG 1987 Tissue distribution of insulin-like growth factor I and II messenger ribonucleic acid in the adult rat. Endocrinology 120:1279-1282

44. Shamay A, Cohen N, Niwa M, Gertler A 1988 Effects of insulin-like growth factor I on deoxyribonucleic acid synthesis and galactopoiesis in bovine undifferentiated and lactating mammary tissue. Endocrinology 123:804-809

45. Wunder SJ, Turvey A, Forsyth IA 1989 Stimulation of DNA synthesis in cultures of ovine mammary epithelial cells by insulin and insulin-like growth factors. J Endocrinol 123:319-326

46. Davis SR, Gluckman PD, Hart IC, Henderson HV 1987 Effects of injecting growth hormone or thyroxine on milk production and blood plasma concentration of insulin-like growth factors I and II in dairy cows. J Endocrinol $114: 17-24$

47. Prosser CG, Fleet IR, Hart IC, Heap RB 1984 Changes in concentration of insulin-like growh factor 1 (IGF-1) in milk during bovine growth hormone treatment in the goat. J Endocrinol 112:65(abstr)

48. Dehoff MH, Elgin RG, Collier RJ, Clemmons DR 1988 Both type I and II insulin-like growth factor receptors of bovine mammary tissue during the pre- and postpartum periods. Endocrinology 122:2412-2417

49. Hadsell DL, Campbell PG, Baumrucker CR 1990 Characterization of the change in type I and II insulin-like growth factor receptors of bovine mammary tissue during the pre- and postpartum periods. Endocrinology 126:637-643

50. Menke PT, Ganguli S, Hu LB, McGrath MF, Collier RJ 1989 Insulin-like growth receptor characterization in rat mammary tissue during gestation and lactation. 71 st Annual Meeting of the Endocrine Society, Seattle, WA, p 48(abstr)

51. Gresik EW, van der Noen H, Barka T 1984 Transport of ${ }^{125}$ I-labelled epidermal growth factor into milk and effect of sialoadenectomy on milk EGF in mice. Am J Physiol 247:E349-E354

52. Brown KD, Blakeley DM, Fleet IR, Hamon M, Heap RB 1986 Kinetics of transfer of ${ }^{125} \mathrm{I}$-labelled epidermal growth factor from blood to mammary secretions of goats. J Endocrinol 109:325-332

53. Campbell PG, Baumrucker CR 1989 Insulin-like growth factor I and its association with binding protein in bovine milk. J Endocrinol 120:21-29

54. Campbell PG, Baumrucker CR 1988 Secretion of immunoreactive insulin-like growth factor I and its bindings protein from the bovine mammary gland in vitro. 70th Annual Meeting of the Endocrine Society, New Orleans, LA p 148(abstr)

55. Orlowski CC, Brown AL, Ooi GT, Yang YW-H, Tseng LY-H, Rechler MM 1990 Tissue, developmental, and metabolic regulation of messenger ribonucleic acid encoding a rat insulin-like growth factor binding protein. Endocrinology 126:644-652

56. Phillips AF, Rao R, McCracken D, Koldovsky O 1990 Presence of insulin-like growth factor-I (IGF-1) in rat milk and the absorption of IGF-1 by the suckling rat. Pediatr Res 27:49A(abstr) 